\title{
MECHANISM OF WATER DISTRIBUTION ON LEMON FARM LAND
}

\author{
${ }^{1}$ Alfian Hamsi, ${ }^{2}$ Tulus Burhanuddin Sitorus \\ ${ }^{1,2}$ Fakultas Teknik Universitas Sumatera Utara \\ ${ }^{1}$ Email : alfian_hamsi@yahoo.com \\ ${ }^{2}$ Email : tburhanudin@yahoo.com
}

\begin{abstract}
Pump is mechanical device to increase the pressure energy of a fluid. Generaly pumps are used to lift the water from low level to high level. These are of two types,namely reciprocating pumps and centrifugal pumps. On centrifugal pumps the centrifugal force or variation of pressure due to rotation is responsible for their operation or working.

The program of community services as implementation of sciences and technology intended to introduced and give skill training about water supply units to the community at Desa Sempa jaya ,Kabupaten Deli-Karo. In this area the people have a problem about availibity of water for agricultute, when mountain Sinabung gets eruption the leave of plantation are covered with dust and damaged to citrus plants,in dry season orange plants lack of water even though the success of the harvest is very dependent on water.

The program was carried out by designing, fabricating and erecting the unit of water supply,consist of deepwell pump,piping system, valve,tee,bent,tower tank and panel control.

The result of this community services showed that the capacity of pumps are 6 liter/menit,head are 50-70 meter,power $2 \mathrm{HP}$,speed $1500 \mathrm{rpm}$.capacity of tower tank 5400 liter, the pump may supply the water to tower tank until full about 2 hours, and the farmer may use the water from the tower tank by gravitation about 3 days.
\end{abstract}

\section{Keywords : deepwell pumps,piping,tower tank,valve,elbow,tee.}

\section{INTRODUCTION Analyse the situation}

Farmer groups are the vanguard for increasing agricultural productivity so it needs to be maintained and developed, Farmer groups may strengthen the bargaining position to other institution such as institution of agriculture and institution of marketing (Mulyadi,2001) . Integration method should be carried out also more efficient if managed by groups. Next Farmer groups have to developed as the basis for counseling development for other farming communities. Desa Sempa Jaya (lihat gambar
1.1) is one village at kabupaten Karo, the distance about $75 \mathrm{~km}$ from Medan city, has a fairly extensive agriculture area with a population of 2500 people. This village has moderate climate with minimum temperature about 20-28 ${ }^{\circ} \mathrm{C}$. Average annual rainfall are $1.936,3 \mathrm{~mm}$,in general the most rainfall in September ,October,November and Dcsember (BPS Sumatera Utara,2015).apart from these months there is a dry season which threatens the avaialability of water for farmers until the orange plants lack of water,the plants become stunted until they failed to harvest. Karo soil topography is hilly and the water source is in steep slopes far from the farmers land,so far the 
farmers manually lift the water by carrying buckets from a 30 meters depth to water the land of about two hectares.

While mount Sinabung gets eruption continuously since years 2010 the dust of mount Sinabung has covered the leave of the oranges and branches of the plants, consequently the plants become damaged if don't cleaned and watered with water.

\section{The Purpose and Benefits}

1. Developing knowledge of the people about the importance of enough water for citrus fields according to standards up to optimal yields.
2. Water supply units and parts of water distribution may give benefit to farmer groups of UMKM Sempa Jaya village.

3. In order for cadres to be able to socialize to the community be able to water their plants with a mechanization system.

4. Law aware society can complete its business entity with legal legality.

\section{Theoretical basis}

The science and technology applied to the farming community can be seen in figure 1.1 as follow :

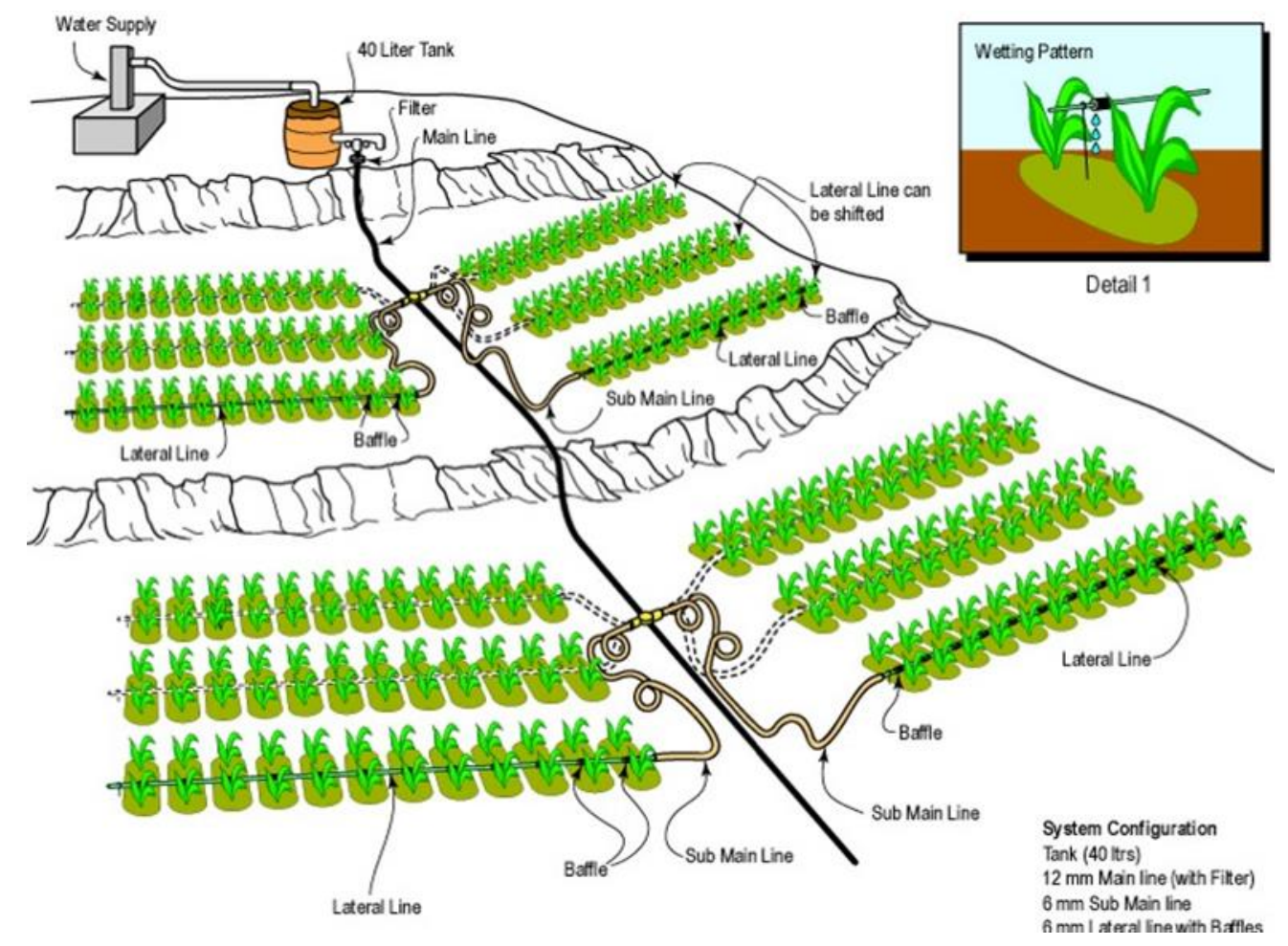

Figure 1.1 : The science and technology applied to the farming communit. 


\section{Pump Engine :}

These are called centrifugal pumps because the centrifugal force or variation of pressure due to rotation is responsible for their operation or working, and height $\mathrm{d}$ of the water has some parameters such as,qapacities, and speed, the empiric results shows above parameters will affect pump performances. Where head $(\mathrm{h})=$ $\mu^{2} / 2$ g (TR.Bangga 2009). and $\mu$ velocity of slip at radii (r) pompa.

\section{Component parts :}

1. Impeller : The function of impeller is to force the water into a rotating motion and shroud around the impeller is to direct the water through the impeller.

2. Casing : is provide for housing the impeller and supporting the bearing provided for the shaft carrying the impeller..

3. Suction Pipe: It is a pipe,whose upper end is connected with the pump on suction side and lower end is submerged in the source of water, the velocity of water in the suction pipe should be between $1.5 \mathrm{sd}$
$3.0 \mathrm{~m} /$ det. (TR.Bangga.2009).

4. Delivery pipa : Lower end of this pipe is connected to the outlet of the pump and takes the water upto the required head and then delivers it ,the velocity of water in the delivery is kept equal or slighty higher than velocity in suction pipe. (TR.Bangga.2009).

Net Positive Suction Head (NPSH) : The term NPSH is very common in the pump industry. It is defined as the gauge reading in meters of water taken on the suction side of the pump at the center line minus gauge vapour pressure in meters of water at the pumping temperature plus velocity head at that points.

Static Lift $(h)=\left(h_{s}+h_{d}\right)$, and

Suction head of a pump $=\mathrm{h}_{\mathrm{s}}+\mathrm{h}_{\mathrm{fs}}+\mathrm{V}_{2}^{2} / 2 \mathrm{~g}$.

The program of community services mono year used deep well pump with power 2 HP speed 5600rpm (figure 1.2.) .

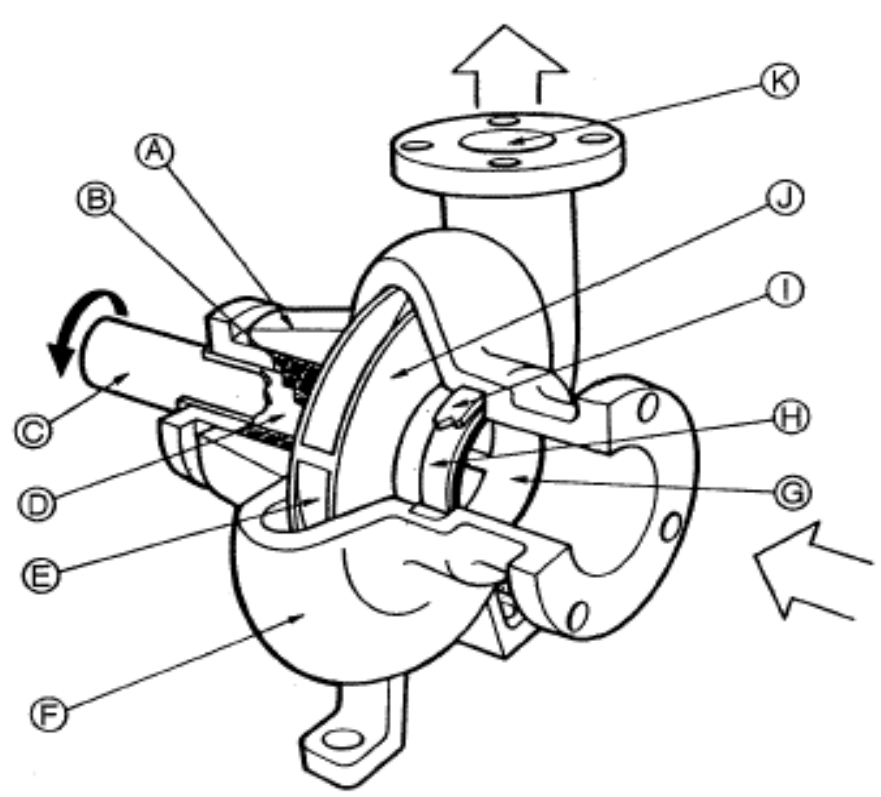

A Stuffing Box

B Packing

C Shaft

D Shaft Sleeve

E Vane

F Casing

G eye of Impeller

H Impeller

I Casing wear ring

$\checkmark$ Impeller

K Discharge nozzle

Figure 1.2: Design and pump engine parts. 


\section{METHOD}

\section{Problem solving framework}

The goal of implementing this science and technologi of mechanization of water distribution is the farmers of oranges at Sempa jaya village-Berastagi Kabupaten Karo with arranged a farmer group Sempa Jaya village.

The design of mechanization water distribution,piping,tower tank,can be seen at figure 1.3 as follow

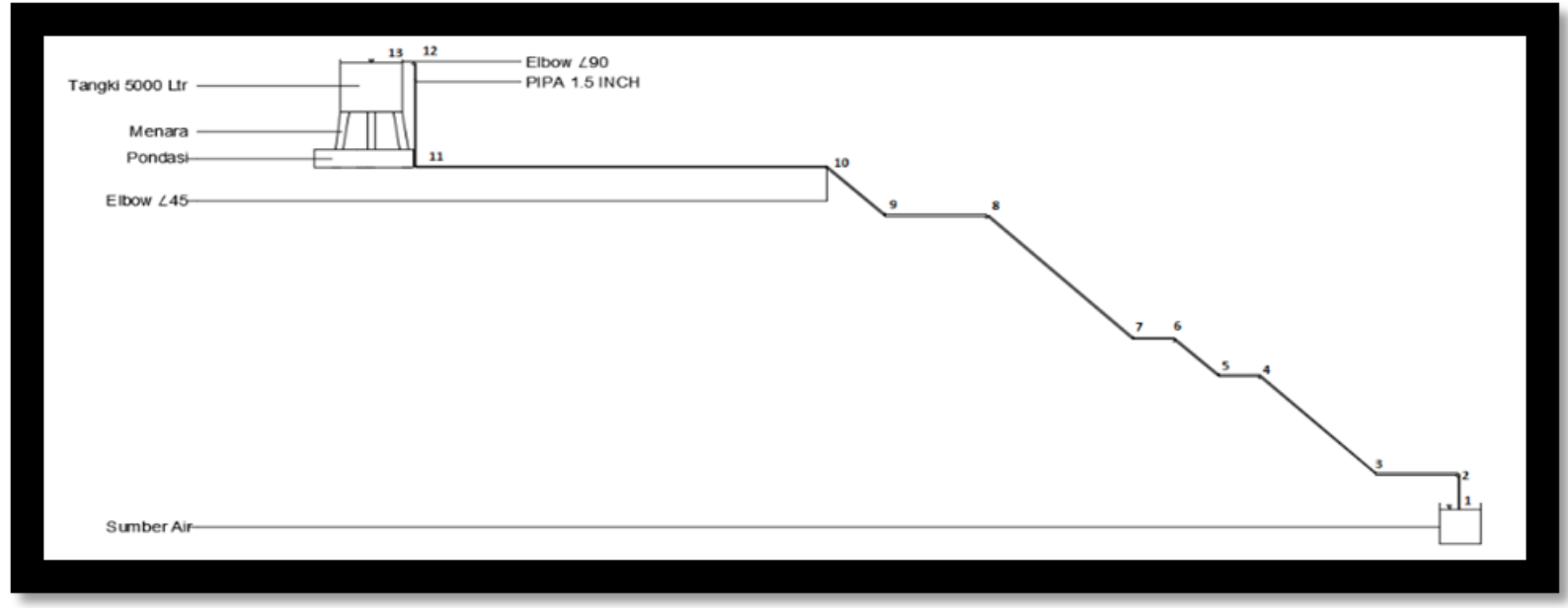

Figure 1.3 The design of mechanization water distribution at lemon plantation.

Mechanization water distribution,piping system,fabrication of tower tank,serves to increase water from the source of water which is located in the valley of the lemon garden and 70 degree land slope. Submersible pump put into the source of the water works and lift water through pipes and valves to tower tank located at uppest. The components of this system as follow:

1. Submersible pump power $2 \mathrm{HP}$, head 80 meter, Qapacities 5 liter/jam,for pumping water from intake to outake at tower tank.

2. Pipes PVC size $3 / 4$ dan $1 / 2$ inci, for distributing water from pump to tower tank.

3. Elbow, for bending pipes at hilly land not flat.

4. Tee dan bent, tee for device water, bent for bending pipes

5. Elbow iron to frame the water tower, bent for bending pipes.

6. Tower tank Qapacities 5400 liters for storage the water from the source next used to water lemon plants

7. electrical Instalations of submersible pump.

\section{Problem Solving Method}

Base on the above matters, a solution is made to overcome the problems faced by partners through the literature study,machine manufacturing,surveys,tower tank,piping system, training and maintenance. In general solution may describes as follow :

\section{a. Procurement of Equipment}

Procurement of equipment such as submersible pump and piping may help the farmers to solve their problems about lack of water on the lemon

plants.

\section{b. Workshop and tutorial}

\section{c. Demonstration}

The extension activities is very important to do as part of transfering technology to partner 
including operation of the engine and how to maintenance the units.

\section{d. Tutorial and Practice}

20 farmers at Sempa Jaya village are participated in tutorial and practice held by LPPM USU,three times class about two hours for five weeks. Every one has to be active to follow the rule of waorkshop about theoretical and practical. Every one may talk about their experiences about pump,piping,tower tank, and how to predict the fault of the engine. The farmers are given the complete unit of engine for provide water, next the engine can water the land of lemon garden. Participating this workshop the farmers get more understand and has skill to operate and maintenance the engine,finally the farmers will get better harvest.

\section{RESULT AND DISCUSSION}

\section{Evaluation of Activities}

The training and workshop program for operation and maintenance pump engine for farmers at Sempa Jaya village will carry out continuously, which will be held every two months at farmers land.

The outcomes, shows at table 1.1 as follow:

Table 1.1 Outcomes.

\begin{tabular}{|c|c|c|c|}
\hline No & Problems & Results & Outcomes \\
\hline 1 & $\begin{array}{l}\text { Don't understand } \\
\text { slighty about } \\
\text { technology. }\end{array}$ & $\begin{array}{l}\text { Participants can } \\
\text { understand about } \\
\text { technology. }\end{array}$ & $\begin{array}{l}\text { Participants has } \\
\text { more confident } \\
\text { about } \\
\text { technology. }\end{array}$ \\
\hline 2 & $\begin{array}{l}\text { Less of technical } \\
\text { knowledge }\end{array}$ & $\begin{array}{l}\text { Participants can } \\
\text { understand about } \\
\text { the basic of } \\
\text { pumping system. }\end{array}$ & $\begin{array}{l}\text { Participants has } \\
\text { more confident } \\
\text { working on } \\
\text { technology. }\end{array}$ \\
\hline 3 & $\begin{array}{l}\text { Short training of } \\
\text { pumping system } \\
\text { and maintenance. }\end{array}$ & $\begin{array}{l}\text { Participants can } \\
\text { understand of } \\
\text { basic of pump } \\
\text { and maintenance. }\end{array}$ & $\begin{array}{l}\text { Participants } \\
\text { able to maintain } \\
\text { the pumps. }\end{array}$ \\
\hline 4 & $\begin{array}{l}\text { Short training of } \\
\text { tower } \quad \text { tank } \\
\text { system } \\
\text { maintenance. }\end{array}$ & $\begin{array}{l}\text { Participants can } \\
\text { understand of } \\
\text { tower tank and its } \\
\text { maintenance. }\end{array}$ & $\begin{array}{l}\text { Participants } \\
\text { able to } \\
\text { fill,maintain } \\
\text { and wash the } \\
\text { tower tank.. }\end{array}$ \\
\hline
\end{tabular}


Hamsi, A. Mechanism Of Water Distribution On Lemon Farm Land

\begin{tabular}{|c|c|c|c|}
\hline 5 & Mindset & $\begin{array}{l}\text { Participants able } \\
\text { to change their } \\
\text { mindset that } \\
\text { water the lemon } \\
\text { plant has a } \\
\text { standard. }\end{array}$ & $\begin{array}{l}\text { Participants } \\
\text { water the lemon } \\
\text { plant } \\
\text { standardly. }\end{array}$ \\
\hline 6 & $\begin{array}{l}\text { Work alone } \\
\text { without group }\end{array}$ & $\begin{array}{lr}\text { Participants } & \text { able } \\
\text { to change } & \text { the } \\
\text { method } & \text { of } \\
\text { working } & \text { by } \\
\text { group. } & \end{array}$ & $\begin{array}{l}\text { Participants } \\
\text { able to work by } \\
\text { group. }\end{array}$ \\
\hline 7 & $\begin{array}{ll}\text { Skill } & \text { trigger } \\
\text { dicipline } & \end{array}$ & $\begin{array}{l}\text { Participants able } \\
\text { be discipline on } \\
\text { maintain } \\
\text { engine }\end{array}$ & $\begin{array}{lr}\text { Participants } & \\
\text { able } & \text { be } \\
\text { discipline } & \text { on } \\
\text { maintain and } \\
\text { operation the } \\
\text { engine. }\end{array}$ \\
\hline
\end{tabular}

\section{Supporting Factors}

On community services partners agreed to help physically and thingking for develop the their business of lemon plants.

\section{Obstacle Factors}

1. Less knowledge of technology.

2. Less of skill about technology..

3. Short course of maintenance of pump system.

4. Mindset.

5. Work alone not in group.

6. Skill trigger the discipline 


\section{CONCLUSION AND RECOMMENDATION}

\section{Conclusion}

After participating the workshop tree times, so many mindset change of the farmers. They get more knowledges about technology in general especially pump technology and its parts, so the confidency,skill for mechanic daily produce excellence in the water distribution by using mechanism way until harvest is not depend on the nature, which is rainy season and dry season,finally,the farmers may live independently,discipline and harvest maximum. Besides that the farmers also happy to join the workshop,they may improve the knowlegde of pump technology,standard for watering the lemon plant, how to operate the pump and its maintenance.

\section{Recommendation}

Good and systematically Maintenance and operation management for water distribution able to operate the pump optimal, the suggestion for the group of may perform as follows:

1.Operates the pump according to manual guide book.

2.The rotating parts should be lubricated regularly.

3.Tower tank should be cleaned regularly by drain the water every three months, and supply the raw water again.
4.Pipes line has to control regularly,if there is a leakages fix it as soon possible.

\section{REFERENCES}

1. T.R.Bangga.2009. Hydraulic Machines. Khanna Publisher.Delhi-6

2. Mulyadi.2001. Manajemen Pemasaran Pertanian.IPB.Press.

3. Colton, Prof. J.S. 2009. Manufacturing Processes and Engineering. Georgia Institute of Technology.

4. Jhon Vernon,2000. Introduction to Engineering Material,Third Edition,Mc.Millan.London.

5. Charm.2002.The Fundamental of Food Engineering. The Avi Publishing Co.Inc. Connecticut.

6. Espito,Thrower,2001.Machine Design.New York,Delmar Publisher,Inc.

7. Hadi Prayitno,2005,Pembangunan Ekonomi Pedesaan.Jokyakarta,Liberty.

8. Dawan Raharjo,2004,Transparansi Pertanian,Industrilisasi dan Kesempatan Kerja.Jakarta,UI Press.

9. Kanisius,2006.Budi Daya Jeruk Lemon,Buku Kita.Gramedia. 